\title{
Nový časopis o literatúrach a kultúrach strednej Európy
}

\author{
Anna Zelenková (Praha)
}

Informovat’ o založení nového vedeckého časopisu sa môže na prvý pohlad zdat ako správa, ktorá iba dokladá d’alšiu položku do knižničných databáz. Ako vieme, tak šanca na úspech periodika vzniká napr. v prípade menej frekventovanej, ale relevantnej témy a koncepčného zamerania, za čím stojí aj výrazná osobnost', silná redakčná rada alebo monotematické čísla. Výhodou je aj komparatívne, interdisciplinárne a metodologické uchopenie problematiky s vyprofilovaným odborovým základom, ktorý sa stáva akousi „vlajkovou lod’ou“ s „nákladom“ netradičných, originálnych vízií, myšlienok a nápadov. V decembri 2019 vyšli prvé dve čísla nového periodika s názvom Stredoeurópske pohlady a jeho podtitul „Časopis pre jazyk, literatúru, kultúru a médiá“ vypovedá o širšej polytematickej orientácii oscilujúcej medzi filológiou a areálovými štúdiami. Filologicko-kulturologický záujem o problematiku štúdia strednej Európy (ktorý časopis slubuje) by mal pritiahnut vedeckú obec najmä z tých krajín, ktoré si vytvárajú svoju podobu stredoeurópskej identity ako určitej ,jednoty v mnohorakosti“.

Časopis začal vydávat' Ústav stredoeurópskych jazykov a kultúr Fakulty stredoeurópskych štúdií Univerzity Konštantína Filozofa v Nitre. Šéfredaktorka Dominika Hlavinová Tekeliová sa môže opriet’ o redakčnú radu, ktorej členom je aj vedúci špičkového tímu Stredoeurópske medziliterárne vztahy Tibor Žilka, jedna z osobností tzv. nitrianskej semioticko-komunikačnej školy, ktorú doplnil o nové aspekty intertextuálnych a imagologických výskumov. Stredoeurópske pohlady nadväzujú na almanach Kultúra a súčasnost' vydávaný v rokoch 2004-2018, na ktorom mal hlavnú zásluhu prozaik, literárny vedec, kritik a bývalý redaktor Slovenských pohladov Peter Andruška, dlhoročný pracovník a zakladatel' vydávajúceho Ústavu. Ako vidiet' už z prvých dvoch čísel, tak na rozdiel od volnejšieho historicko-kultúrneho záberu tohto almanachu majú v Stredoeurópskych pohl'adoch prevažovat texty s tematickým zameraním na literatúru, kultúru a médiá krajín tzv. V4 (Česká republika, Mad’arsko, Pol'sko, Slovensko) a sú vítané rôzne prístupy podporujúce interdisciplinárnu a odborovú konfrontáciu. Koncepcia časopisu predpokladá uprednostňovanie imagologicko-komparatívnych analýz etnických stereotypov, štúdia obrazov „inakosti“ a ich multikultúrne reflexie v slovesných textoch. $\mathrm{V}$ popredí by mali byt aj sondy do života minorít a menšinových literatúr a skúmanie židovského elementu ako archetypálneho znaku stredoeurópskeho medzikultúrneho dialógu.

Vyššie uvedenú orientáciu potvrdzuje aj úvodné číslo, ktoré monotematicky mapuje etnické stereotypy v literatúrach krajín V4 vo vzájomných vztahoch a historických súvislostiach, a druhé číslo sa zameralo na podrobnejšiu rekognoskáciu židovskej literatúry a na jej dejinnú skúsenost $\mathrm{v}$ slovansko-neslovanskom priestore strednej Európy. Časopis dodržiava klasické rozčlenenie na štúdie, materiály, recenzie či spravodajskú rubriku a príspevky by mali byt (s ohladom na nadnárodnú orientáciu časopisu) publikované vo všetkých stredoeurópskych jazykoch (okrem slovenčiny však najmä v angličtine). Bude sa uprednostňovat najmä slavistický a komparatívny aspekt, pretože si redakcia kladie za ciel' eliminovat' izolované analýzy v rámci systému jednej národnej literatúry. Preto sa jednou z podmienok pre publikovanie príspevku stane jeho vztahový aspekt zakomponovaný bud' teoreticky, alebo v literárnohistorickej interpretácii, vychádzajúcej z materiálu aspoň dvoch literatúr. Už z prvého čísla je zrejmá ambícia časopisu prezentovat sa ako otvorená, ale tematicky zjednocujúca platforma pre hlbšie poznanie kultúrnych dejín strednej Európy, a to prostredníctvom jazyka a literatúry. 
Anna Zelenková (Praha)

Nový časopis o literatúrach a kultúrach strednej Európy

doc. PhDr. Anna Zelenková, Ph.D.

Slovanský ústav AV ČR, v. v. i.

Valentinská 1, 11000 Praha 1, Česká republika

zelenkova.anna@centrum.cz

Toto dílo Ize užít v souladu s licenčními podmínkami Creative Commons BY-SA 4.0 International (https://creativecommons.org/licenses/by-sa/4.0/legalcode). Uvedené se nevztahuje na díla či prvky (např. obrazovou či fotografickou dokumentaci), které jsou v díle užity na základě smluvní licence nebo výjimky či omezení příslušných 